\title{
Bioproducts against food-borne pathogenic bacteria
}

Lisianne Brittes Benitez ${ }^{*}$, Ariana Pereira dos Santos ${ }^{1}$, Ana Paula Muller' ${ }^{1}$, Thamires Klein de Souza ${ }^{1}$

'University of Santa Cruz do Sul, Santa Cruz do sul, Brazil *Corresponding author, email: lisianne@unisc.br

\begin{abstract}
Advances in biotechnology research show the rising generation of a variety of products derived from microbial, plants and animal sources. These products are known as "bioproducts" or "natural products". The preservation of the microbiological quality of foods without the use of chemical preservatives has become a challenge stimulating new researches on conservation alternatives. The aims of this study were the assessment of the the antibacterial activity of several bioactive compounds: essential oils of orange, lavender, green and red mandarins; ethanol extract of oregano and protein hydrolyzed from shrimp shell against Escherichia coli and Staphylococcus aureus isolated from foods, and the comparison between two different methods used in the screening of natural products with potential antibacterial activity. The antibacterial activities of the natural compounds were determined using agar diffusions tests and bioautography methods. The Minimum Inhibitory Concentration (MIC) and Minimum Bactericidal Concentration $(M B C)$ were determined for the essential oils of orange and lavender, and the ethanolic oregano extract. The essential oils of orange and lavender and the ethanolic oregano extract showed antimicrobial activity against all bacteria tested in the study. The agar disk diffusion and the bioautographic methods showed no significant difference in the evaluation of the biological activity of natural products.
\end{abstract}

Keywords: antibacterial activity, food quality, natural products

\section{Introduction}

The growth of biotechnology today

is remarkable, and its impact on society

is irreversible. Studies show the increasing availability of bioproducts derived from plants, animal, and microbial sources. New products with antimicrobial properties can derive from the extracts, and essential oils from plants, organic acids, hormones, polysaccharides, and proteins. The increased sensibility of the consumers, who demand the application of "smooth technologies" to food preservation to keep the natural features of the products and guarantee their quality reducing the application of chemical preservatives instigates the search for new preservation alternatives to use in food (Zoz et al., 2014; Calo et al., 2015).

The search for bioactive compounds has been intensified because microorganisms are not resistant to these substances, turning them into safer foods, especially to the toxicological point of view. Even with high concentrations of those substances, they seem not to cause any toxic effect; they can be applied to different products, and materials (Solórzano-Santos \& MirandaNovales, 2011).

The action of natural plant compounds occurs by the synergism of the antimicrobial phytochemicals present in the plant: mainly flavonoids, tannins, saponins and terpenoids 
(Negi, 2012).

Most of the natural products act altering the permeability and the integrity of the membrane of the bacterial cell. The complexity of the chemical composition of the natural products mirrors the availability of several mechanisms of action of these biological compounds on the bacteria (Bajpai et al., 2012; Nazzaro, 2013).

Bacteria contamination of foods reduces the shelf life, causes losses to the food industry, and may lead to the development of infections, that may cause death among the consumers. Among the bacteria that most frequently are involved in epidemics of food-related diseases, we must highlight Staphylococcus aureus and Escherichia coli. S. aureus, a natural element of human skin microbiota is a gram-positive bacteria mainly found in highly processed foods. The gram-negative bacteria E. coli derives from fecal material and contaminated surfaces (Fueyo et al., 2005). Inadequate practices during the food processing chain allow the multiplication of pathogenic microorganisms, and the possible development of diseases caused by the consumption of contaminated foods (Sousa, 2008).

The biological activity of natural products can be assessed using different methods. The choice of the method of analysis is crucial to quantify the possible biological activities of natural products. (Sanchéz \& Kouznetsov, 2010).

This study aimed to assess the antibacterial activity of several bioactive compounds on the bacteria $E$. coli and S. aureus isolated from foods and to compare different methods used in the screening of natural products with potential antibacterial activity.

\section{Materials and Mathods}

Natural products

The following bioactive compounds were used in the study: essential oils of organic orange (Citrus sinensis), green and red organic mandarins (Citrus reticulata var. Montenegrina) obtained on the Ecological Citrus Farmer Cooperative (Ecocitrus); lavender oil (Lavandula dentata), ethanolic extract of oregano (Origanum vulgare) and protein hydrolyzate from shrimp shells obtained on UNISC Pharmacognosy and
Food Technology laboratories. For the analysis of antibacterial activity, the essential oils were diluted with Tween 80 (0.5\% v/v). The ethanolic extract of oregano was diluted in DMSO (Dimethyl sulfoxide) at $10 \%$. The shrimp hydrolyzate was diluted in sterile distilled water $(5 \mathrm{mg} / \mathrm{mL})$.

\section{Microorganisms}

Bacterial strains of $E$. coli and S.aureus used for the assessment of the antibacterial activity of the natural compounds derived from the bacteria collection of the Food Hygiene Laboratory from the Science and Technology Institute, Federal University of Rio Grande do Sul. Besides these bacterial strains, we used the reference ATCC strains E. coli ATCC 25922 and S. aureus ATCC 25923. These strains belong to the microbiology laboratory of the University of Santa Cruz do Sul. All strains were stored at -21 C in BrainHeart Infusion Broth (BHI; Oxoid, Basingstoke, UK) containing $20 \%(\mathrm{v} / \mathrm{v})$ glycerol and propagated in the same medium at $37^{\circ} \mathrm{C}$ before use.

Assessment of antibacterial activity of bioactive compounds

Disc diffusion method

The antibacterial activity of natural products was detected by the Kirby-Baver disc diffusion method (Benitez et al. 2011). Aliquots of $10 \mu \mathrm{L}$ of each product, reconstituted at a concentration of $200 \mathrm{mg} / \mathrm{mL}$ and filtered $(0,22$ um Millipore ${ }^{\circledR}$ filter) were applied to sterile cellulose discs $(6 \mathrm{~mm})$ that were later left at room temperature in a laminar flow chamber until the complete evaporation of the diluent. Then the disks impregnated with the bioactive compounds were disposed on Mueller Hinton agar (Meck®) plates, previously inoculated with a bacterial suspension containing $10^{8} \mathrm{cell} / \mathrm{s} / \mathrm{mL}(0.5 \mathrm{McF}$ arland scale) of each microorganism. Erythromycin and sulfamethoxazole + trimethoprim were used as positive controls. Sterile saline $(0.85 \%)$ was used as a negative control. The plates were left for an hour at environmental temperature for the spreading of the applied samples and, then, incubated for 24 hours at the optimum temperature $\left(35-37^{\circ} \mathrm{C}\right)$ for growth of each microorganism tested. The inhibition of bacterial growth was assessed by the measurement of the inhibition halo around 
the disks impregnated with biologically active substances.

\section{Bioautography assay}

Aliquots of $10 \mu \mathrm{L}$ from each natural product (sterilized through a filter of 0,22 $\mu \mathrm{m}$ membrane) were applied on sterile plates of silica gel G60 $\mathrm{F}_{254}$ (Merck®). Positive (5\% erythromycin) and negative (saline $0.85 \%$ ) controls were equally applied. Hexane: ethyl acetate (1:9) were used as elvent. After the migrations of the constituents on the TLC plates, they were incubated at $30^{\circ} \mathrm{C}$ for 2 hours to the complete evaporation of the solvent and exposed to UV light for 20 minutes to eliminate the contaminants. The plates were covered with $9 \mathrm{~mL}$ of agar $\mathrm{MH}$ containing $3 \times 10^{8}$ $\mathrm{CFU} / \mathrm{mL}$ of each test microorganism and, later, incubated at $37^{\circ} \mathrm{C}$ for $24 \mathrm{~h}$. After that, the plates were sprayed with an aqueous solution of $2,3,5$ triphenyltetrazolium chloride (TTC) $(20 \mathrm{mg} / \mathrm{mL}$ ) and incubated $\left(35-37^{\circ} \mathrm{C}\right)$ for 4 hours. The growth inhibition was indicated by white zones (halos) in chromatogram. The halos were measured using a precision gauge caliper.

MIC and MBC determinations by microdilution methods

For MIC determination, it was used the broth microdilution method, following the Clinical and Laboratory Standards Institute (2012) with some modifications. We chose to define MIC of oregano extract and oils of orange and lavender once it expressed the highest activity against the strains used in the agar disc diffusion method. Serial dilutions were performed in sterile polystyrene 96-well plates at a concentration range from 2 to $0.0156 \mathrm{~mL} / \mathrm{mL}$ for the orange and lavender oils, and from 66.67 to $1.56 \mathrm{mg} /$ $\mathrm{mL}$ for the ethanol extract of oregano. The final concentration of each strain suspension (E. coli and S. aureus food isolates and ATCC strains) was adjusted to give a final concentration of $10^{8}$ cells $/ \mathrm{mL}$ (0.5 McFarland) with $10 \mu \mathrm{L}$ of bacterial suspension in BHI (Oxoid, Basingstoke, UK) in a final volume of $200 \mu \mathrm{L}$. One hundred microliters $(100 \mu \mathrm{L})$ of each natural product $+100 \mu \mathrm{L}$ of $\mathrm{BH}$ was used as negative controls, and $10 \mu \mathrm{L}$ of each strain tested $+100 \mu \mathrm{L}$ of $\mathrm{BH}$ as positive controls. The plates were covered with a sterile plate sealer, carefully mixed and incubated at $35^{\circ} \mathrm{C}$ for $24 \mathrm{~h}$.
After the incubation, $20 \mu \mathrm{L}$ of resazurin dye for each well was added and, then, the colorimetric reaction was observed. The permanence of the blue color $\mathrm{n}$ the holes was interpreted as a lack of bacterial growth and the development of pinkred, as the presence of bacterial activity. The MIC value was taken as the lowest concentration of the test agent and caused total inhibition (100\%) of bacterial growth. To determine the $M B C$, aliquots of $20 \mu \mathrm{L}$ were taken from each well and inoculated in 96-well plates containing $100 \mu \mathrm{L} \mathrm{BHI}$ and incubated at $35^{\circ} \mathrm{C}$ for 24 hours. After the incubation, $20 \mu \mathrm{L}$ of resazurin dye was added to each well and, then, the colorimetric reaction was observed. MBC was defined as the lowest concentration of assayed samples which remained blue.

\section{Statistical analysis}

Numerical data are expressed as an average \pm standard deviation. The statistical significance of differences between the values of individual means was calculated using the chi-square test with significance level of $p<0.05$, using SPSS Statistics 17.0 software. All experiments were performed in triplicate.

\section{Results and Discussion}

The agar disc diffusion tests showed that the ethanolic extract of oregano and the essential oils of orange and lavender affected the growth of all tested bacterial strains. The oils of red and green bergamot inhibited only the strain of S. aureus ATCC 25923 (Figure 1). Hosni et al. (2010) reported the chemical constituents of Citrus reticulata Blanco and Citrus sinensis Osbeck peel oil. The authors found that monoterpene hydrocarbons (97.59-99.3\%), with limonene (92.52-97.3\%) and $\beta$-pinene (1.37-1.82) were the major constituents.

The ethanolic oregano extract showed the highest growth inhibition in comparison with the other products tested. All strains tested using ethanolic oregano extract displayed some degree of inhibition on growth, however for both strains of $S$. aureus (food isolate and ATCC) the inhibition halos were greater than $20 \mathrm{~mm}$. A previous study comparing the antibacterial activity of oregano extract with an alcoholic extract of the mastic- 


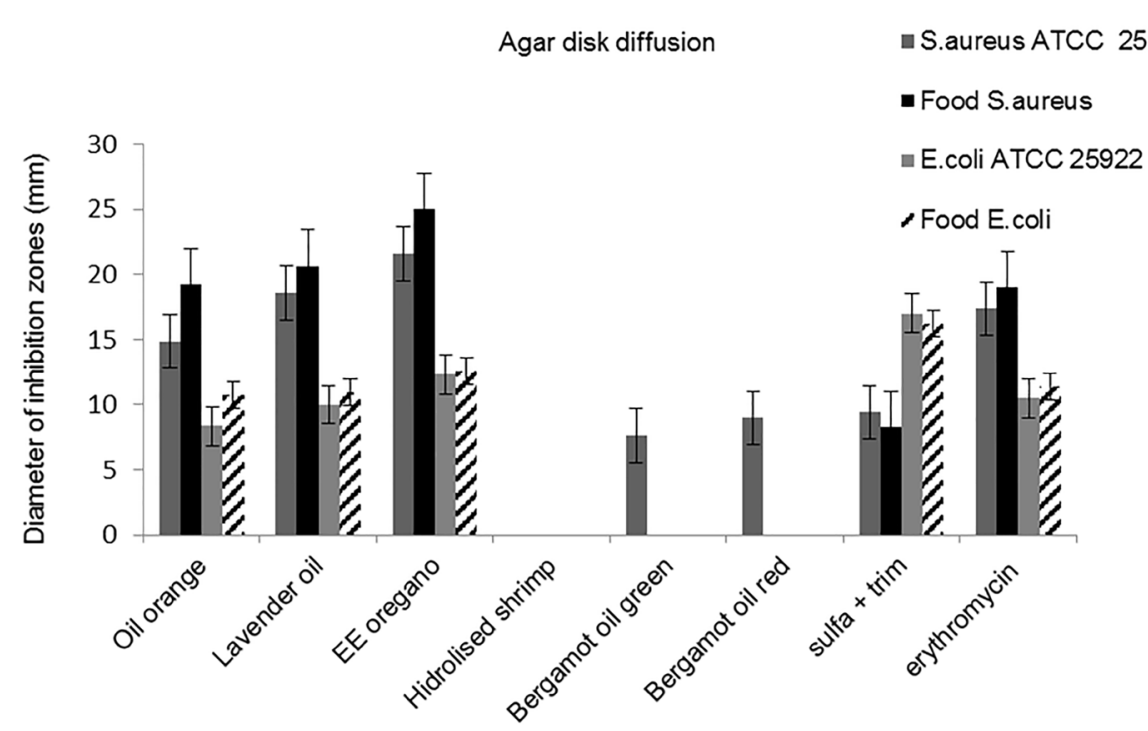

Figure 1. Antibacterial activity of bioactive compounds by agar diffusion. Bars represent the standard deviation from triplicate determinations.

red tree (Schinus terebenthifolius) described that oregano inhibited the growth of $S$. aureus ATCC 6538 and Bacillus cereus ATCC 11778, with halos ranging between 9 and $11 \mathrm{~mm}$ respectively (Degáspari et al., 2005). Aromatic plants are excellent sources of bioactive compounds that can be extracted using several processes. The main components found in the essential oregano oil are oxygenated monoterpenes (53.8\%), and monoterpene hydrocarbons (26.4\%). Among these compounds, the main antibacterial activity is associated with the presence of carvacrol and thymol (Teixeira et al., 2013). The action of the ethanol extract of oregano has also been confirmed by Weerakkody et al. (2010) against essential food pathogens: the Gram-negative bacteria E. coli and Salmonella Typhimurium, and the Gram-positive S. aureus and Listeria monocytogenes. Boligon et al. (2014) found the spathulenol as the most abundant component in the essential oil of Scutia buxifolia Reissek, also found in Origanum vulgare. The spathulenol was active against Staphylococcus aureus (MIC $=500$ $\mu \mathrm{g} / \mathrm{mL}$ ) and Escherichia coli (250 $\mathrm{\mu g} / \mathrm{mL})$.

Among the tested essential oils, lavender oil was the only one that showed activity against all microorganisms tested (Gram-positive and negative) but was especially active against $S$. aureus. The main essential oil constituents are 1,8-cineole, camphor, and L-fenchone (Touati et al., 2011). The essential lavender oil is active against various Gram-positive, Gram-negative bacteria and fungi (Hanamanthagouda et al., 2011).

The protein hydrolyzed from shrimp shell had no activity on the species of bacteriawetested in this work. The primary active compound in the protein hydrolyzed from shrimp shell is chitosan, which stands as an inhibitor of pathogens. Its mechanisms of action are due to its cationic feature that interferes with the metabolism in the bacterial cell surface, destabilizing the membrane (Chung et al., 2004). The products made from the shrimp shall inhibit several types of Gram-positive and Gram-negative bacteria such as E. coli, Salmonella Typhimurium, S. aureus and B. cereus, but the intensity of the inhibition effect depends on the molecular size and the type of bacteria (Benhabiles et al., 2012; Siriporn et al., 2013; Arancibia et al., 2014).

The oils of orange and lavender and the ethanolic extract of oregano inhibited the growth of $S$. aureus more than the growth of $E$. coli, both in strains of the bacteria isolated from foods, and reference ATCC strains. The different level of activity could be explained by the permeability of the bacterial walls, which have a different chemical composition. The membrane of Gram-negative bacteria is more selective to the entrance of compounds than that of Grampositive bacteria (Silhavy, 2010).

The results of bioautography show the antibacterial activity in different bio-compounds (Figure 2). 
The bioautography separates the compounds from a complex mixture through thinlayer chromatography (TLC) and determines the antimicrobial activity of the isolated substances. This test provides more objective information on the bioactivity of the natural compounds in comparison with disk diffusion, MIC and MBC tests.
Bioactive compounds separated through TLC should migrate to the agar, and the revelation consists of the application of a tetrazolium salt that will indicate the zone of the inhibition halo through the absence of any color (Choma \& Grzelak, 2011) (Figure 3).

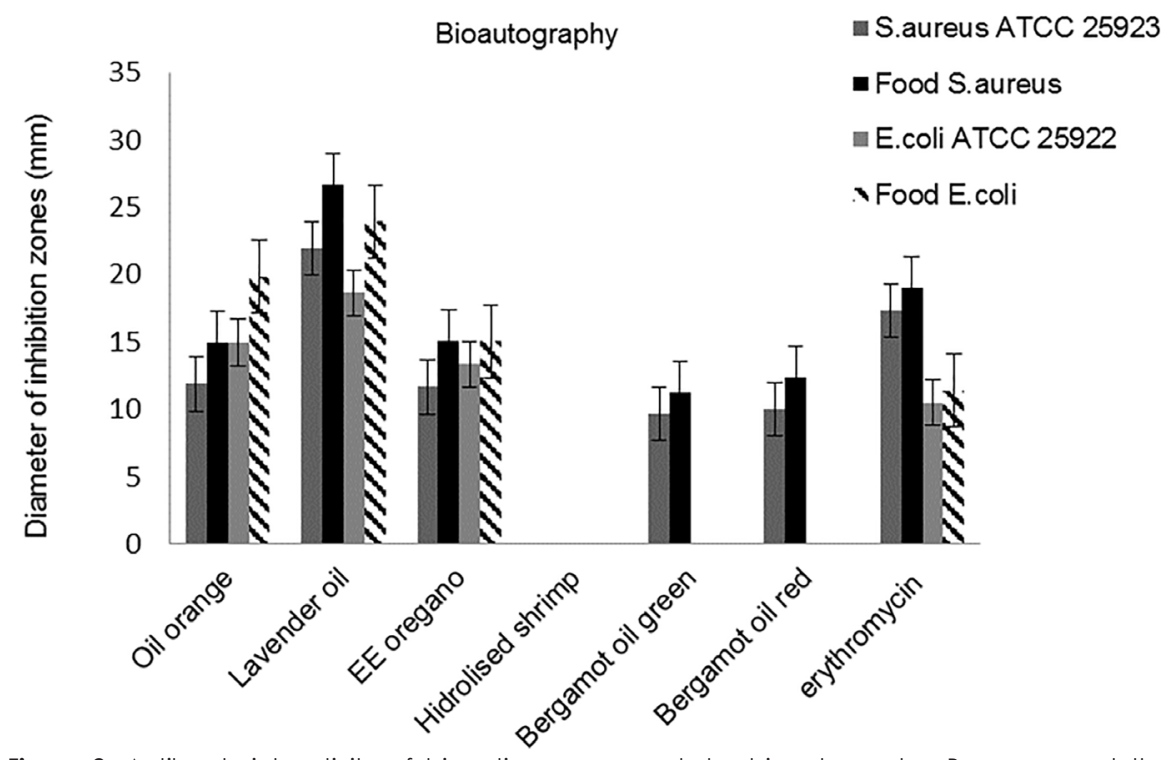

Figure 2. Antibacterial activity of bioactive compounds by bioautography. Bars represent the standard deviation from triplicate determinations.

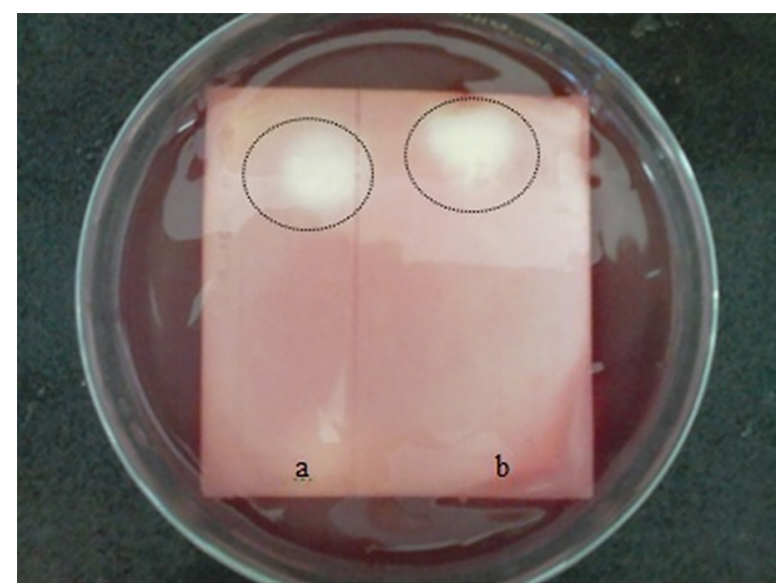

Figure 3. Bioautography assay of orange oil against ATCC strain of S. aureus (a) and S. aureus (b) isolated from food.

As analyzing the diameters of halo inhibition zones obtained by the bioautographic method, we observed a difference in size in comparison with the results of the agar-disk diffusion. Even the same, this difference had no statistical significance $(p>0,05)$. These results corroborate those presented by Valgas et al. (2007). In their study with natural products, the authors compared the bioautographic and the agar diffusion methods, and the results showed no significant differences.
The agar diffusion method and the bioautography are also qualitative tests of antimicrobial activity. However, the agar diffusion method stands out because of its simplicity, low cost and high reproducibility (Ncube, 2008; Das 2010).

The ethanolic extract of oregano and lavender oil showed higher activity against the strains of $S$. aureus, compared to the antibiotic erythromycin. This result highlights the potential applicability of these bioactive products 
against this pathogen (Table 1). Nostro et al. (2004) when evaluating the susceptibility of methicillin-susceptible and methicillin-resistant Staphylococci to oregano oil observed inhibition of both types of pathogens to the same extent with MIC values for carvacrol of 0,015-0,03\%, v/v.

Although the agar diffusion test, essential oils had presented lower values of inhibitory activity than the ethanolic extract of oregano. According to the results of the MIC, the essential oils of orange and lavender were inhibiting the growth of microorganisms at the lowest tested concentrations (Table 2).

Table 1. Inhibitory activity of erythromycin and bioproducts against Staphylococcus aureus.

\begin{tabular}{lcc}
\hline & $*$ *. aureus ATCC 25923 & *Food S. aureus \\
\hline Erythromycin & $17.35 \pm 0.5 \mathrm{~mm}$ & $19.01 \mathrm{~mm} \pm 0.3 \mathrm{~mm}$ \\
Oregano & $21.58 \pm 3 \mathrm{~mm}$ & $25.01 \pm 2 \mathrm{~mm}$ \\
Lavender oil & $20.67 \pm 3 \mathrm{~mm}$ & $22.23 \pm 3 \mathrm{~mm}$ \\
\hline *Average diameter of the inhibition zone $(\mathrm{mm})$ by agar diffusion method. \pm Standard deviation out of three independent experiments.
\end{tabular}

Table 2. MIC and MBC of bioactive compounds.

\begin{tabular}{|c|c|c|c|c|c|c|}
\hline \multirow[b]{2}{*}{ Test-microorganism } & \multicolumn{2}{|c|}{ Oregano (mg/mL) } & \multicolumn{2}{|c|}{$\begin{array}{l}\text { Orange oil (EA) } \\
\qquad(\mathrm{mg} / \mathrm{mL})\end{array}$} & \multicolumn{2}{|c|}{$\begin{array}{l}\text { Lavender oil } \\
\text { (mg/mL) }\end{array}$} \\
\hline & MIC & $M B C$ & MIC & $\mathrm{MBC}$ & MIC & $M B C$ \\
\hline S. aureus ATCC 25923 & 50 & 66.67 & 0.21 & 0.21 & 0.21 & 0.21 \\
\hline S. aureus (food) & 25 & 50 & 0.21 & 0.21 & 0.053 & 0.053 \\
\hline E. coli ATCC 25922 & 25 & 25 & 0.027 & 0.027 & 0.027 & 0.053 \\
\hline E. coli (food) & 25 & 25 & 0.053 & 0.053 & 0.027 & 0.053 \\
\hline
\end{tabular}

The low diffusivity of the plant oil components in the agar produced smaller halos and a better response in MIC because the substance would not need to spread and would be in direct contact with the microorganism in a liquid medium. Its lipophilic nature may harm the diffusion of the oils in agar, and therefore emulsifying agents should be used to facilitate the diffusion of the lipophilic agents. However the amount of emulsifier used must be pondered, as this can interfere with the activity of the substance upon the microorganism (Espina et al., 2011).

Foodborne pathogens used in this study were inhibited by lower concentrations of the orange and lavender oils. We observed the highest efficiency, lowest MIC, and MBC against the Gram-negative microorganisms. This result agrees with the data reported by Trajano et al. (2010) in the investigation of the oil of Cinnamomum zeylanicum against food-related bacteria.

Oils are complex mixtures of compounds of different classes, and the substances present may have a high affinity for the membrane of Gram-negative bacteria and destabilize it (Sharififar et al., 2007). Porin channels and the form of intracellular diffusion of the constituents are the main factors that will determine the effectiveness of the oils in Gram-negative bacteria (Gal et al., $2011)$. Higher concentrations of oregano extracts were required in this study to inhibit the growth of the strains of $E$. coli we used, in comparison with the study of Krishnan et al. (2014).

\section{Conclusion}

Based on the results obtained we shall conclude that the bioactive compounds evaluated in this study, except hydrolyzed protein from shrimp shell, showed promising biological activity against bacteria isolated from food.

There was no statistically significant difference in measures of inhibitory activities of natural products among bioautographic and agar disc diffusion methods. The essential oils of orange and lavender had an excellent performance to inhibit bacteria at lower tested concentrations. Therefore, the natural products can contribute to reducing or eliminate the use of chemical additives and to improve the shelf life and food safety.

\section{Acknowlegments}

The authors are grateful to FAPERGS 
(Fundação de Amparo à Pesquisa do Estado do Rio Grande do Sul) and CNPa (Conselho Nacional de Desenvolvimento Científico e Tecnológico) for financial support.

\section{References}

Arancibia, M., Alemán, A., Calvo, M.M., LópezCaballero M.E., Montero P., Gómez-Guillén, M.C. 2014. Antimicrobial and antioxidant chitosan solutions enriched with active shrimp (Litopenaeus vannamei) waste materials. Food Hydrocolloids, 35: 710-717.

Bajpai, V.K., Baek, K.H., Kang, S.C. 2012. Control of Salmonella in foods by using essential oils: a review. Food Research International, 45: 722-734.

Benitez, L.B., Correa, A., Daroit, D., Brandelli, A. 2011. Antimicrobial activity of Bacillus amyloliquefaciens LBM 5006 is enhanced in the presence of Escherichia coli. Current Microbiology, 62 (3): 1017-1022.

Benhabiles, M.S., Salaha, R., Lounici, H, Drouiche, N., Goosen, M.F.A., Mameri, N. 2012. Antibacterial activity of chitin, chitosan and its oligomers prepared from shrimp shell waste. Food Hydrocolloids, 29 (1): 48-56.

Boligon, A.A., Piana, M., De Brum, T.F., Froeder, A.L.F., Belke, B.V., Schwanz T.G., Mario, D.N., Alves, S.H., Athayde, M.L. 2014. Scutia buxifolia Reissek essential oil: in vitro antioxidant and antimicrobial activities. Anais da Academia Brasileira de Ciências, 86 (3): 1463-1469.

Calo, J.R., Crandall, P.G., O'Bryan, C.A., Ricke, S.C. 2015. Essential oils as antimicrobials in food systems - A review. Food Control, 54: 111-119.

Choma, I.M., Grzelak, E.M. 2011. Bioautography detection in thin-layer chromatography. Journal of Chromatography A, 1218 (19): 2684-2691.

Chung, Y., Su, Y., Chen, C., Jia, G., Wang, H., Wu, J.C.G., Lin, J. 2004. Relationship between antibacterial activity of chitosan and surface characteristics of cell wall. Acta Pharmacologica Sinica, 25 (7): 932-936.

Clinical and Laboratory Standards Institute. 2012. Methods for dilution antimicrobial susceptibility tests for bacteria that grow aerobically: approved standard M07-A9, 8th ed. Clinical and Laboratory Standards Institute, Wayne, PA.

Das, K., Tiwari, R.K.S., Shrivastava, D.K. 2010. Techniques for evaluation of medicinal plant products as antimicrobial agent: Current methods and future trends. Journal of Medicinal Plants Research, 4 (2): 104-111.

Degáspari, C.H., Waszczynskyj, N., Prado,
M.R.M. 2005. Antimicrobial activity of Schinus terebenthifolius Raddi. Ciência e Agrotecnologia, 29 (3): 617-622.

Espina, L., Somolinos, M., Lorán, S., Conchello, P., García, D., Pagán, R. 2011. Chemical composition of commercial citrus fruit essential oils and evaluation of their antimicrobial activity acting alone or in combined processes. Food Control, 22 (6): 896-902.

Fueyo, J.F., Mendoza, M.C., Martín, M.C. 2005. Enterotoxins and toxic shock syndrome toxin in Staphylococcus aureus recovered from human nasal carriers and manually handled foods: epidemiological and genetic findings. Microbes and Infection, 7 (2): 187-194.

Hanamanthagouda, M.S., Kakkalameli, S.B., Naik, P.M., Nagella, P., Seetharamareddy, H.R., Murthy, H.N. 2010. Essential oils of Lavandula bipinnata and their antimicrobial activities. Food Chemistry, 118 (3): 836-839.

Hosni, K., Zahed, N., Chrif, R., Abid, I., Medfei, W., Kallel, M., brahim, N.B., Sebei, H. 2010. Composition of peel essential oils from four selected Tunisian Citrus species: Evidence for the genotypic influence. Food Chemistry, 123 (4): 1098-1104.

Nazzaro, F., Fratianni, F., De Martino, L., Coppola, R., De Feo, V. Effect of Essential Oils on Pathogenic Bacteria. 2013. Pharmaceuticals (Basel), 6(12): 1451-1474.

Ncube, N.S., Afolayan, A.J., Okoh, A.I. 2008. Assessment techniques of antimicrobial properties of natural compounds of plant origin: current methods and future trends. African Journal of Biotechnology, 7 (12): 1797-1806.

Negi, P.S. 2012. Plant extracts for the control of bacterial growth: Efficacy, stability and safety issues for food application - Review. International Journal of Food Microbiology, 156: 7-17.

Nostro, A., Blanco ,A.R., Cannatelli, M.A., Enea, V., Flamini, G., Morelli, I., Sudano, R.A., Alonzo, V. 2004. Susceptibility of methicillin-resistant staphylococci to oregano essential oil, carvacrol and thymol. FEMS Microbiology Letters, 230 (2): 191-195.

Krishnan, K.R., Babuskin, S., Azhagu, S.B.P., Sasikal, A M., Sabina, K., Archana, G., Sivarajan, M., Sukumar, M. 2014. Antimicrobial and antioxidant effects of spice extracts on the shelf life extension of raw chicken meat. International Journal of Food Microbiology, 171: 32-40.

Sanchéz, J.G., Kouznetsov, V.V. 2010. Antimycobacterial susceptibility testing methods for natural products research. Brazilian Journal of Microbiology, 41: 270-277. 
Sharififar, F., Moshafi, M.H., Mansouri, S.H., Khodashenas, M., Khoshnoodi, M. 2007. In vitro evaluation of antibacterial and antioxidant activities of the essential oil and methanol extract of endemic Zataria multiflora Boiss. Food Control, 18 (7): 800-805.

Silhavy, T.J., Kahne, D., Walker, S. The Bacterial Cell Envelope. 2010. Cold Spring Harbor Perspectives in Biology, 2(5): 1-16.

Siriporn, K., Saovaluk, L., Wassawan, K., Ratchaneewan, A. 2013. Control of Listeria monocytogenes on sliced bologna sausage using a novel bacteriocin, amysin, produced by Bacillus amyloliquefaciens isolated from Thai shrimp paste (Kapi). Food Control, 32 (2): 552-557.

Solórzano-Santos, F., Miranda-Novales, M.G. 2012. Essential oils from aromatic herbs as antimicrobial agents. Current Opinion in Biotechnology, 23 (2): 136-141.

Sousa, C.P. 2008. The Impact of Food Manufacturing Practices on Food borne Diseases. Brazilian Archives of Biology and Technology, 51 (4): 815-823.

Teixeira, B., Marques, A., Ramos, C., Serrano, C., Matos, O., Neng, N.R., Nogueira, J.M.F., Saraiva, J.A., Nunes, M.L. 2013. Chemical composition and bioactivity of different oregano (Origanum vulgare) extracts and essential oil. Journal of the Science o Food and Agriculture, 93 (11): 27072714.

Touati, B., Chograni, H., Hassen, I., Boussaid, M., Toumi, L., Brahim, N.B. 2011. Chemical Composition of the Leaf and Flower Essential Oils of Tunisian Lavandula dentata L. (Lamiaceae). Chemistry and Biodiversity, 8 (8): 1560-1569.

Trajano, V.N., Lima, E.O., Travassos, A.E., Souza, E.L. 2010. Inhibitory effect of the essential oil from Cinnamomum zeylanicum Blume leaves on some food-related bacteria. Food Science and Technology, 30 (3): 771-775.

Valgas, C., Souza, S.M., Smânia, E.F.A., Smânia Jr. ,A. 2007. Screening methods to determine antibacterial activity of natural products. Brazilian Journal of Microbiology, 38 (2): 369-380.

Zoz, L., Carvalho, J.C., Soccol, V.T., Casagrande, T.C., Cardoso, L. 2014. Torularhodin and Torulene: Bioproduction, Properties and Prospective Applications in Food and Cosmetics - a Review. Brazilian Archives of Biology and Technology, 58 (2): 278-288.

Weerakkody, N.S., Caffin, N., Turner, M.S, Dykes, G.A. 2010. In vitro antimicrobial activity of lessutilized spice and herb extracts against selected food-borne bacteria. Food Control. 21 (10): 14081414. 